\title{
THE SPECIFIC DYNAMIC RESPONSE TO PROTEIN OF INDI- VIDUALS SUFFERING FROM DISEASE OF THE HYPOPHYSIS
}

\author{
By MARGARET WOODWELL JOHNSTON \\ (From the Department of Internal Medicine, University of Michigan, Ann Arbor)
}

(Received for publication September 30, 1931)

Many attempts have been made to assign to the hypophysis the regulation of the increase in heat production which follows the ingestion of a protein meal, just as the thyroid gland appears to regulate the level at which the basal metabolic rate is set.

Plaut (1) in 1922, studied the response of groups of individuals to a standard meal consisting of 200 grams of chopped meat, 50 grams of fat, 200 grams of bread, and $500 \mathrm{cc}$. of coffee. She found that the maximal increase in heat production that resulted from this meal, occurred 45 minutes after its ingestion, was maintained through the second hour, and was definitely decreasing in the third. The increase in heat production above the basal value in normal individuals was 24 to 52 per cent. In what she described as "hypophyseal obesity," (2) the response varied from -3 to +18 per cent. She stated that a normal basal metabolic rate coupled with a lowered specific dynamic response to protein, is characteristic of disease of the hypophysis, and therefore of great diagnostic value. Plaut (2) (3) (4), Plaut and Schadow (5), and Kestner, Plaut, and Schadow (6), have reported many determinations in confirmation of this earlier work. Similar results have been obtained by Knipping (7). Liebesny (8) fed a similar meal (200 grams meat, 100 grams bread) to a group of normal individuals, 4 dwarfs, 2 acromegalics, 1 case of hypophyseal tumor, 4 cases of infantilism, and individuals suffering from conditions related to "disturbances of the autonomic nervous system." He determined the increase in heat production 2 hours after the ingestion of the test meal, and concluded that the specific dynamic response of the normal individual to the above meal is 30 per cent above the basal, with a variation of \pm 10 per cent. A decrease, or complete absence, occurred in disturbances of the pituitary body (hypophyseal dwarfs, hypophyseal tumor), obesity, especially of hypophyseal origin, and in conditions related to disturbances of the autonomic nervous system (Raynaud's disease, scleroderma). Further, he found that the administration of a preparation of anterior lobe of the hypophysis resulted in an increase in the specific dynamic response. In a later paper (9), he reports that diathermy of the hypophysis of individuals suffering 
from disturbances of the sex glands resulted in an appreciable increase in their specific dynamic response. Bernhardt (10) found a low specific dynamic response in conditions other than disturbances of the pituitary body. He believes that it is possible that some relationship exists between the hypophysis and the increase in heat production, following a protein meal, but that other endocrine glands may be concerned as well. A similar position is taken by Gantenberg (11), in a very extensive review of the clinical significance of determinations of the specific dynamic response.

The experiments carried out by Plaut and her associates have been criticized with regard to the meal fed and the technique used. Pollitzer and Stolz (12) found that the maximal increase in heat production resulting from the ingestion of 250 grams of ground meat alone occured in the third to fifth hour. They further noted that if the heat production was determined only one to two hours after the ingestion of the meat, four-fifths of the subjects they studied gave negative results. They attribute the early increase observed by Plaut to the large amount of carbohydrate in the test meal. Plaut (4) herself answers these criticisms by asserting that the ingestion of fairly large amounts of carbohydrate with meat favor rapid emptying of the stomach, so that the specific dynamic response is observed more quickly than when meat alone is fed. Dürr (13) makes the same criticism of the work of Plaut, and points out that an individual without any evidence of hypophyseal disease exhibited no significant specific dynamic response in three hours, and only 18 per cent in five hours. Lublin (14) has questioned the technique used by Plaut. He feels that she obtained too great variation in the basal metabolic rate in normal individuals, and points with skepticism to several fasting respiratory quotients greater than one. He, likewise, feels that a single determination of the heat production one to two hours after the test meal is not sufficient for generalization. From his own work he concludes that a low specific dynamic response is not diagnostic of pituitary disease. Jaguttis (15) came to the same conclusion. Lauter (16) in a careful study of obesity, points out that the specific dynamic response of normal individuals to protein varies within very wide limits, and that since the normal variations are so large abnormalities can be postulated only if no increase at all results from the ingestion of protein. Therefore, he questions the diagnostic value of such a procedure. Gessler, Kraus, and Rettig (17) also found considerable variation in a series of normals. They believe that no conclusions can be drawn from a small section of the curve, but that the whole course of the reaction must be followed.

Attempts have been made to solve the question by injury, or removal of the hypophysis. Knipping (7) injured the hypophyses of two dogs by the Cushing method, and found a low specific dynamic response to 
protein, which was returned to normal in both cases by the administration of an anterior lobe preparation (Präphyson). Foster and Smith (18) found that rats after the removal of the hypophysis exhibited no specific dynamic response to the administration of glycine, and that the restoration of the normal response occured only if extracts of both anterior and posterior lobe were simultaneously injected. Contrary results, however, were obtained by Gaebler (19), working in Lusk's laboratory, who found that dogs, from whom the hypophysis had been removed, responded normally to a standard protein meal.

It is clear that no agreement exists among investigators in regard to the relationship between the pituitary body and the specific dynamic action. Part of the confusion, no doubt, arises from laxity in the selection of material. Consequently, we have restricted our studies to patients in whom physical abnormalities of the hypophysis had been certainly demonstrated.

\section{PROCEDURE}

It seemed desirable to eliminate the effect of ingested carbohydrate. Accordingly the test meal consisted of 300 grams of sirloin steak, freed from all extraneous fat, ground and fried in a small amount of butter. The subject was allowed to drink water with the meat. In the first subject studied 700 grams of meat were fed on two different occasions, but this amount was too large to be eaten readily. The basal metabolic rate was determined before the meat was given, and the heat production again measured at the intervals recorded in Table $I$. When a significant increase in heat production was observed under satisfactory conditions, the experiment was discontinued. Determinations were carried out by means of a Tissot spirometer, and the gas analyses were made with the Henderson apparatus.

The significant physical findings in each case are recorded in the appendix.

\section{RESULTS}

Examination of Table I makes it clear that each of the six subjects studied, responded to the ingestion of 300 grams of meat, with a definite increase in heat production. The maximal responses to the same meal varied from 18 to 28 per cent above the basal.

Case number 248006 was studied on October 16, 1930, and a response of only 12 per cent was observed, although his heat production was followed for five hours after the ingestion of the meat. Opportunity was given us, however, to repeat this determination. This time, in the second hour, his heat production was 28 per cent above the basal level. It is probable that a true basal value was not obtained in the first experiment. If we recalculate this experiment in terms of the second basal, we find an increase in heat production of 21 per cent in the first experiment 


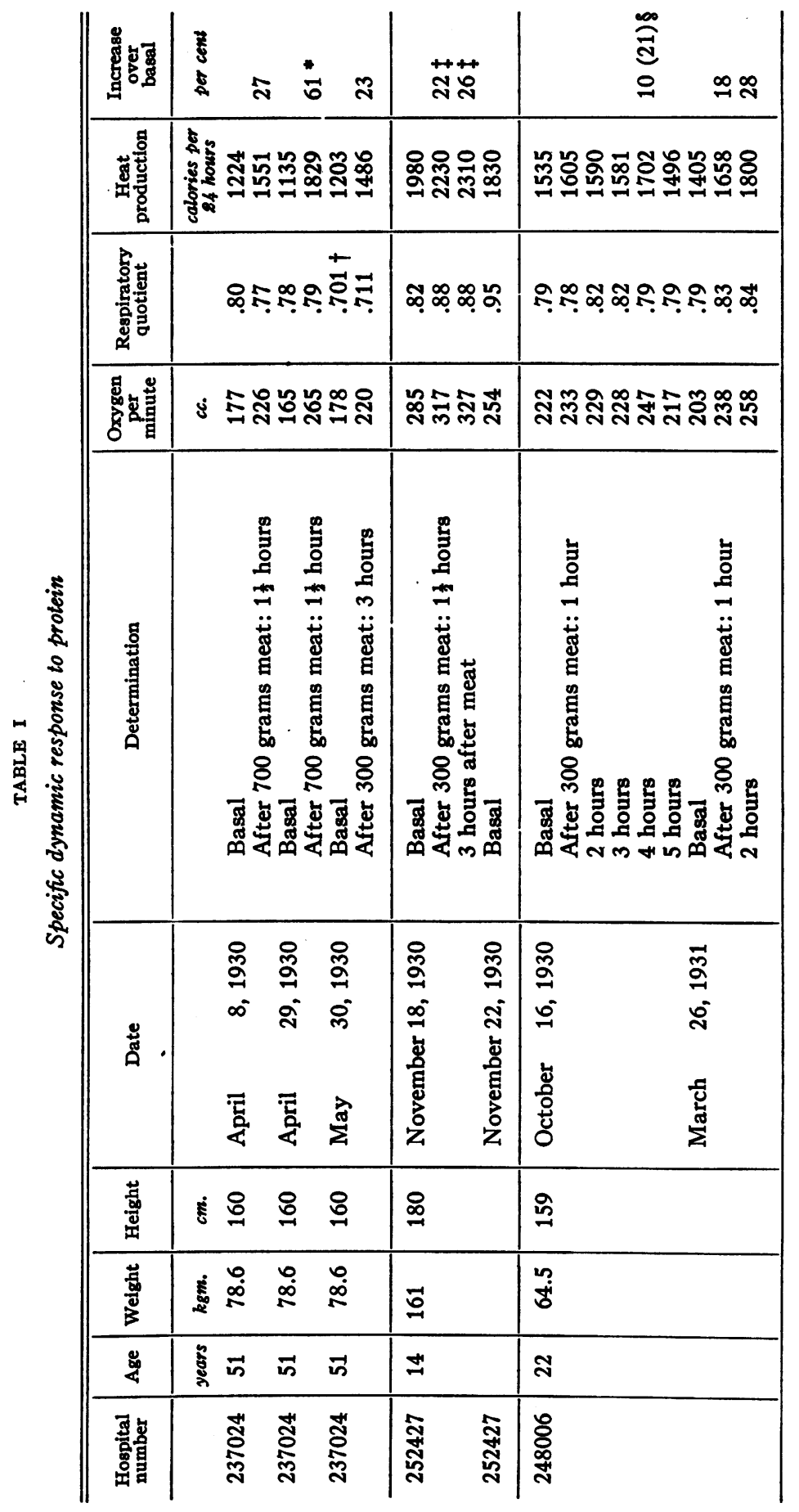


MARGARET WOODWELL JOHNSTON

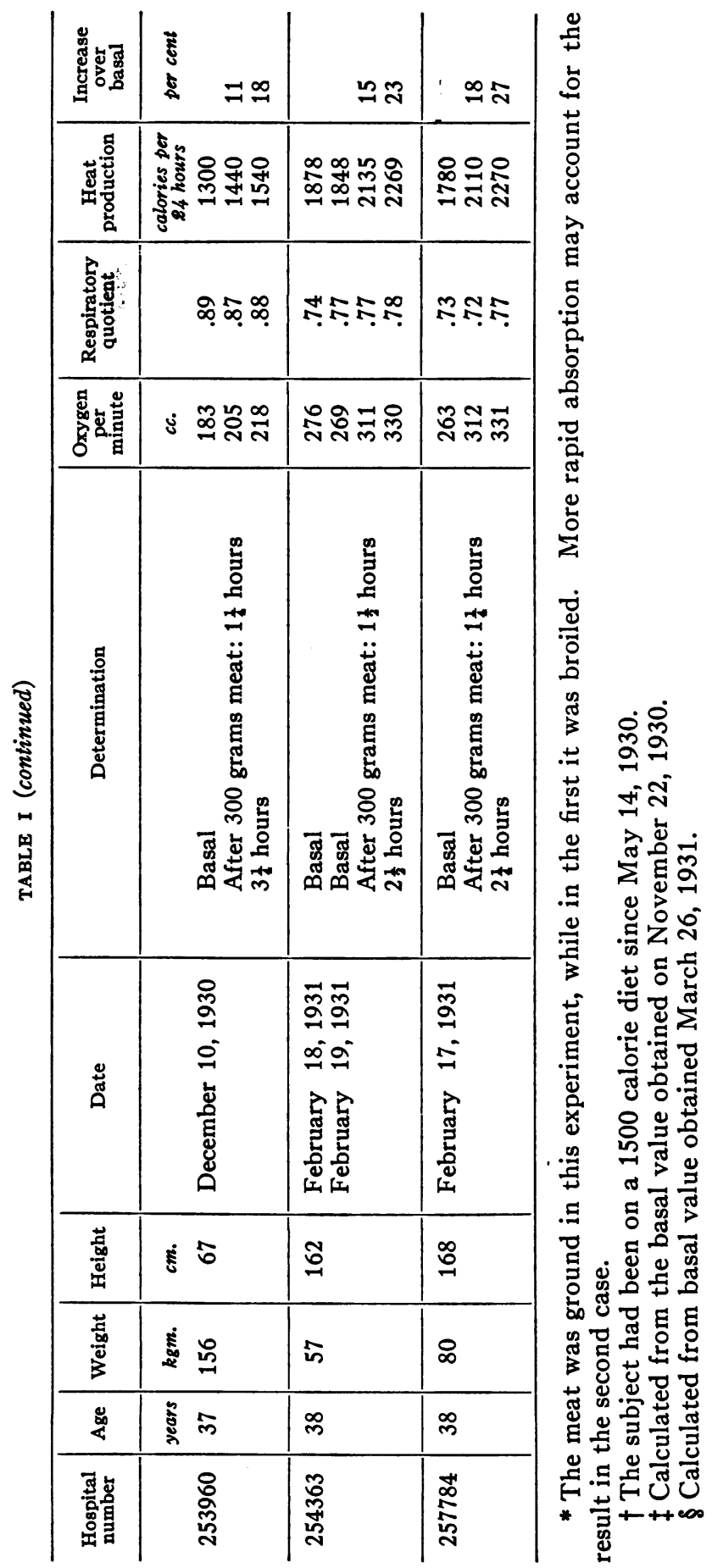


in the fourth hour after the protein meal. If, however, this experiment had not been repeated it would have been necessary to conclude that here at least was a definitely lowered response to protein. It is evident that these six individuals, each of whom had some involvement of the pituitary body, exhibited a large response to a protein meal.

\section{DISCUSSION}

The diversity of the results obtained by various investigators is not surprising when the difficulties encountered in this field are fully appreciated. In recent times there has been great enthusiasm displayed in attributing disease to endocrine abnormalities. However, it still remains true that a definite diagnosis of pituitary disease should be based on a demonstration of definite physical abnormalities of this organ. If the clinical material thus far presented is examined with such criteria in mind, insufficient cases remain on which to base the published conclusions.

Further, in the case of the "normal" human subject, a uniformity of results comparable to those reported by Lusk (20) for the dog has not been obtained. Missal and Johnston (21) found it impossible to secure a consistent response to ingested sucrose or glycine in a normal subject maintained on a constant diet. Further, Benedict and Carpenter (22) state, "that while the ingestion of protein in almost any amount invariably produces an increase over the basal metabolism (which may be 25 per cent for several hours, and for short periods may rise to 45 per cent), no definite mathematical relationship between the amount of protein ingested and the increment in the total metabolism can be noted from these values."

Further, in critically evaluating the literature it is necessary to bear in mind that evidence exists that the state of nutrition (11) influences the height of the specific dynamic response, and that Coleman and DuBois (23) have shown it to be lowered in fever.

Recent animal experiments suggest that the liver is responsible for the increased heat liberated during protein metabolism. It is not clear whether this extra heat production results from a general increase in oxidative processes throughout the body, stimulated by some intermediary product of protein metabolism, as Lusk (20) has suggested, or whether it results from exothermic reactions involved in the intermediary metabolism of protein, as for example, conversion of amino acids to glucose, as Geelmuyden (24) thinks.

Bollman, Mann, and Magath (25) (26) showed that deaminization of the amino acids was prevented by hepatectomy, while Wilhelmj and Mann (27) (28) (29) found that the administration of amino acids to hepatectomized dogs did not increase the metabolism. These authors are inclined to interpret their results as evidence that not the amino acids, but other intermediate products of their metabolism, are the stimulators of cellular oxidation throughout the body. 
Recently Dock (30), by excluding from the circulation various portions of the bodies of rats, found that at least 85 per cent of the heat evolved as the specific dynamic action of protein was liberated in the abdominal viscera. He concluded that "the liver is probably the chief site and possibly the only site of the intermediary metabolism of those amino acids which raise the metabolic rate, and that at least 80 per cent of the specific dynamic action of these amino acids is due to the increased energy liberated by the hepatic cells during protein digestion."

\section{CONCLUSION}

1. Six individuals with definite abnormality of the pituitary body responded to the ingestion of a protein meal, with a large increase in heat production.

2. Experiments designed to show the dependence of the specific dynamic action of protein upon the secretory activity of the pituitary body are unconvincing. In fact, recent investigation goes far to demonstrate that the two are quite independent.

\section{BIBLIOGRAPHY}

(1) Plaut, R., Deutsches Arch. f. klin. Med., 1922, cxxxix, 285. Gaswechseluntersuchungen bei Fettsucht und Hypophysis-erkrankungen.

(2) Plaut, R., Deutsches Arch. f. klin. Med., 1923, cxlii, 266. Gaswechseluntersuchungen bei Fettsucht.

(3) Plaut, R., Deutsche med. Wchnschr., 1922, xlviii, 1413. Ueber den respiratorischen Gaswechsel bei Erkrankungen der Hypophysis.

(4) Liebeschütz-Plaut, R., Klin. Wchnschr., 1925, iv, 2153. Über die Prüfung der spezifisch-dynamischen Eiweisswirkung in der Klinik.

(5) Liebeschütz-Plaut, R., und Schadow, H., Deutsches Arch. f. klin. Med., 1925, cxlviii, 214. Über den Aminosäuregehalt des Bluts bei der spezifisch-dynamischen Wirkung des Eiweiss.

(6) Kestner, O., Liebeschütz-Plaut, R., und Schadow, H., Klin. Wchnschr., 1926, v, 1646. Spezifisch-dynamische Wirkung, Hypophysenvorderlappen und Fettsucht.

(7) Knipping, H. W., Deutsche med. Wchnschr., 1923, xlix, 12. Hypophyse und Fettsucht.

(8) Liebesny, P., Biochem. Ztschr., 1924, cxliv, 308. Die spezifisch-dynamische Eiweisswirkung.

(9) Liebesny, P., Klin. Wchnschr., 1927, vi, 52. Untersuchungen über die Beziehungen zwischen Keimdrüsen und Hypophyse und therapeutischexperimenteller Nachweiss der zentralen Regulierung der Keimdrüsen beim Menschen.

(10) Bernhardt, H., Ztschr. f. klin. Med., 1924, xcix, 149. Zur Frage der spezifisch-dynamischen Wirkung der Nahrungszufuhr bei endocrine Erkrankungen.

(11) Gantenberg, R., Ergebn. d. inn. Med. und Kinderh., 1929, xxxvi, 325. Gaswechselbestimmungen zur Untersuchung der klinischen Bedeutung der spezifisch-dynamischen Nahrungswirkung, mit besonderer Berücksichtigung der Fettsucht und der Hyperthyreosen. 
(12) Pollitzer, H., und Stolz, E., Wien. Arch. f. inn. Med., 1924, ix, 307. Untersuchungen zur Pathologie des respiratorischen Stoff wechsels.

(13) . Dürr, R., Klin. Wchnschr., 1925, iv, 1496. Über die Prüfung der spezifisch-dynamischen Eiweisswirkung in der Klinik.

(14) Lublin, A., Klin. Wchnschr., 1926, v, 1263. Zur Klinischen Bedeutung der Gaswechsel-Bestimmung.

(15) Jaguttis, P., Deutsches Arch. f. klin. Med., 1928, clix, 204. Ein Beitrag zur endogenen Fettleibigkeit.

(16) Lauter, S., Deutsches Arch. f. klin. Med., 1926, cl, 315. Zur Genese der Fettsucht.

(17) Gessler, Krauss und Rettig, Verhandl. d. Kongr. f. inn. Med., 1927, xxxix, 227. Studien zur spezifisch-dynamischen Wirkung des Eiweisses.

(18) Foster, G. L., and Smith, P. E., J. Am. Med. Assoc., 1926, lxxxvii, 2151. Hypophysectomy and Replacement Therapy in Relation to Basal Metabolism and Specific Dynamic Action in the Rat.

(19) Gaebler, O. H., J. Biol. Chem., 1929, lxxxi, 41. Animal Calorimetry. XXXVIII. The Specific Dynamic Action of Meat in Hypophysectomized Dogs.

(20) Lusk, Graham, The Science of Nutrition. W. B. Saunders Co., Philadelphia, 1928, 4th ed.

(21) Missal, M. E., and Johnston, M. W., J. Lab. and Clin. Med., 1929, xiv, 314. The Failure of Pituitary Substances to influence the Basal Metabolism, or the Specific Dynamic Response to Food in a Normal Subject.

(22) Benedict, F. G., and Carpenter, T. M., Food Ingestion and Energy Transformations. Carnegie Institution of Washington, Pub. No. 261. 1918.

(23) Coleman, W., and DuBois, E. F., Arch. Int. Med., 1915, xv, 887. Calorimetric Observations on the Metabolism of Typhoid Patients with and without Food.

(24) Geelmuyden, H. C., Ergebn. d. Physiol., 1925, xxiv, 1. Über die spezifischdynamische W.irkung der Nahrungsstoffe und ihre Beziehungen zum Grundumsatz beim Diabetes Mellitus.

(25) Bollman, J. L., Mann, F. C., and Magath, T. B., Am. J. Physiol., 1926, lxxviii, 258. Studies on the Physiology of the Liver, XV. Effect of Total Removal of the Liver on Deaminization.

(26) Mann, F. C., Wilhelmj, C. M., and Bollman, J. L., Am. J. Physiol., 1927, lxxxi, 496. The Specific Dynamic Action of Glycocoll and Alanine with Special Reference to the Dehepatized Animal.

(27) Wilhelmj, C. M., Bollman, J. L., and Mann, F. C., Am. J. Physiol., 1928, lxxxvii, 497. Studies on the Physiology of the Liver. XVII. The Effect of Removal of the Liver on the Specific Dynamic Action of Amino Acids Administered Intravenously.

(28) Wilhelmj, C. M., and Mann, F. C., Surg. Clin. N. Am., 1929, ix, 829. The Specific Dynamic Action of Food.

(29) Wilhelmj, C. M., Bollman, J. L., and Mann, F. C., Am. J. Physiol., 1931. xcviii, 1. A Study of Certain Factors Concerned in the Specific Dynamic Action of Amino Acids Administered Intravenously and a Comparison with Oral Administration.

(30) Dock, William, Am. J. Physiol., 1931, xcvii, 117. The Relative Increase in Metabolism of the Liver and of Other Tissues during Protein Metabolism in the Rat. 


\section{APPENDIX}

\section{CASE RECORDS}

Hospital number-237024. Date of admission-March 18, 1924. Sex-female.

History. Seventeen years before admission the patient underwent a subtotal oophorectomy without change in the character of the menses. Thereafter she considered herself well until four years ago, when she began having attacks of unconsciousness without convulsions. Severe headaches became frequent. A pronounced increase in appetite resulted in a gain in weight of 85 pounds. During the past two years there has been an increasing memory defect, accompanied by definite psychopathic tendencies which caused her to be brought to the Psychopathic Hospital.

Physical examination. Essentially negative, except for pronated feet, and obesity. The neurological examination revealed no physical abnormalities. Kahn test of the blood was negative.

Ophthalmological examination. The visual fields showed a rather generalized contraction with an achromotopsia.

$X$-ray examination. $\mathrm{X}$-ray examination of the skull revealed complete destruction of the pituitary fossa with no evidence of the anterior or posterior clinoid processes.

Diagnosis. Psychosis with organic brain disease, tumor of pituitary gland. This patient was given deep x-ray therapy with resultant relief of headaches and some improvement in visual fields. Date of dischargeJune 17, 1930.

Hospital number-252427. Date of admission-October 30, 1930. Sex-male.

History. Patient was brought to the hospital because of attacks of abdominal cramps 2 or 3 times a week, which were relieved by vomiting. He also suffered from visual difficulties, especially upon awakening in the morning, when he could not see objects distinctly. He had been having mild recurring headaches. Patient claimed that his weight increased from about 100 pounds a year ago to about 165 at admission.

Physical examination. Obese, marked acne about upper part of body. Expression apathetic. Left palpebral fissure narrowed. Kahn test of blood negative.

Ophthalmological examination. Choking of both discs, 2 diopters. Fields show a definite left temporal defect.

$X$-ray examination. Relative destruction of the sella turcica. Depression of the floor and rarefaction of the posterior clinoid processes with diastasis of the main sutures, suggesting severe internal hydrocephalus.

Operation. Diagnosis of pituitary tumor was made and operation performed February 13, 1931, which consisted of osteoplastic craniotomy 
with exploratory puncture into the lateral ventricle that resulted in the escape of a large quantity of fluid. The sella turcica was excavated but there was no tumor of the hypophysis. Patient died February 15, 1931.

Pathological diagnosis. Suprasellar cystic astrocytoma. No direct involvement of pituitary body.

Diagnosis. Tumor of brain (astrocytoma) involving area lying between pineal and pituitary bodies with pressure atrophy of the pituitary body.

Hospital number-248006. Date of admission-August 27, 1930. Sex-male.

History. Six or seven years ago patient began having pain in the back of his neck and visual difficulties. The condition has changed but little since then.

Physical examination. Essentially negative except for moderate obesity. Kahn test of blood was negative.

Opthalmological examination. Bitemporal hemianopsia. Optic atrophy of both eyes.

$X$-ray examination. X-ray studies of the skull reveal destruction of the posterior clinoid processes and marked injury of the anterior with thinning of the floor of the sellaturcica.

Diagnosis. Pituitary tumor. This patient was given deep $\mathrm{x}$-ray therapy with subjective improvement. Date of discharge-October 16, 1930.

Hospital number-253960. Date of admission-November 24, 1930. Sex-female.

History. A year ago the patient noticed visual disturbances not relieved by glasses. The vision of the right eye failed rapidly until she was blind in that eye. A few months ago there was blurring and haziness of vision in the left eye. She had no other important symptoms.

Physical examination. Essentially negative except complete blindness of right eye and irregularity of both pupils. Kahn test of the blood was negative.

Ophthalmological examination. Marked optic atrophy on right and beginning optic atrophy on left. No hemorrhages.

$X$-ray examination. X-ray of the skull showed normal anterior clinoid processes with destruction of the posterior and thinning of the floor of the sella turcica.

Operation. On December 30, 1930 a large pituitary tumor was removed. The patient died January 3, 1931.

Pathological report. Chromophobe adenoma which replaced a large part of the anterior lobe of the pituitary gland.

Diagnosis. Tumor of the pituitary gland.

Hospital number-254363. Date of admission-December 2, 1930. Sex-female. 
History. Patient entered the hospital because of blindness of right eye of about one month's duration, and severe headaches. She had had severe headaches over a period of ten years without other complaints until about one year ago. Since then she has had dyspnea, progressive weakness and dimness of vision. One month ago she suddenly became blind in the right eye.

Physical examination. The physical examination revealed the standard signs of chronic nephritis with hypertension.

Ophthalmological examination. There was a hemorrhagic retinitis of both eyes. Fundus examination showed choked disc for both eyes-4 diopters. Fields could not be obtained for the right eye but there was marked evidence of optic atrophy of the left with great restriction of the visual field on this side. Kahn test of the blood was negative.

$X$-ray examination. Detailed studies of the sella turcica demonstrate a destruction of the floor of the sella turcica and of portions of both the anterior and posterior clinoid processes. Operation was advised against because of the nephritis. The patient was given deep $\mathrm{x}$-ray therapy. Date of discharge March 6, 1931.

Diagnosis. Chronic nephritis with hypertension. Tumor of the pituitary gland.

Hospital number-257784. Date of admission-January 31, 1931. Sex-male.

History. Four years before admission patient began to notice weakness and fatigueability. His physician made a diagnosis of diabetes mellitus. His symptoms were relieved by diet until the past two years, when his symptoms have increased so that he could not work, and he sought relief at the hospital. During the past ten years his wife has noticed a marked alteration in his appearance and temperament. He has changed from an aggressive, interested husband into an irritable and careless one. He himself has noticed a thickening of the lower lip and a thickening and widening of the fingers. He has noticed no visual disturbances.

Physical examination. Ptosis of left upper eyelid. Thick, drooping lip. Tongue strikingly broad and thick. Huge broad hands with thick bulbous fingers. There was a persistent glycosuria of the diabetic type, which was controllable. The glucose tolerance curve was of the diabetic type. Kahn test of the blood was negative.

Ophthalmological examination. The visual fields showed definite right homonymous hemianopsia.

$X$-ray examination. X-ray studies of the skull showed almost complete destruction of the posterior clinoidal processes and apparent thinning of the floor of the sella turcica. X-ray examination of the hands showed the typical changes of acromegaly. 
Operation. A pituitary tumor was removed March 26, 1931. The patient died the following day.

Pathological report. Adenoma of the pituitary gland.

Diagnosis. Acromegaly, diabetes mellitus and tumor of the pituitary gland. 